Alicante Journal of English Studies 25(2012): 137-149

\title{
Staging Plays at Shakespeare's Globe: Then and Now
}

\author{
Ann Thompson \\ King's College London \\ ann.thompson@kcl.ac.uk
}

\begin{abstract}
The reconstruction of the Globe Theatre on London's Bankside had historical accuracy as one of its aims, both in terms of the design and construction of the building itself and, more controversially, in terms of issues to do with performance. Scholars hoped the theatre would become a kind of laboratory in which they could test theories about how the plays might have been staged in Shakespeare's time, and terms like 'authenticity' and 'original practices' were used. This essay discusses the sometimes patchy and unreliable evidence we have about 'original practices' from stage directions, dialogue and accounts of props and costumes; it also explores how the companies using Shakespeare's Globe have used aspects of the building such as the yard, the space under the stage, the trapdoor and so on. And it provides examples of experiments with lighting and sound effects, and more radical ones with casting (gender, race and age) and original pronunciation. Finally, it argues that the theatre is not just a museum but a space for theatrical innovation, now as well as then.
\end{abstract}

The project to rebuild Shakespeare's Globe Theatre in London on or as near as possible to its original site on the Bankside was of course conceived by the American actor, director and producer Sam Wanamaker after his first visit to London in 1949. He founded the Shakespeare Globe Trust in 1970 and worked hard to secure the site and raise money for the reconstruction which was at an early stage when he died in 1993. The theatre was completed in 1997 and the first words to be uttered on its stage, the opening Chorus from Henry $V$, beginning " $\mathrm{O}$ for a muse of fire, that would ascend / The 
brightest heaven of invention" and containing the reference to the theatre as "this wooden O", were spoken by his daughter, the actress Zoe Wanamaker. As an essay on "Rebuilding Shakespeare's Globe" that has appeared regularly in the theatre's programmes explains:

Techniques used in the reconstruction of the theatre were painstakingly accurate. 'Green' oak was cut and fashioned according to sixteenth-century practice and assembled in twodimensional bays on the Bankside site; oak laths and staves support lime plaster mixed according to a contemporary recipe and the walls are covered in a white lime wash. The roof is made of water reed thatch, based on samples found during the excavation.

Of course concessions had to be made to modern safety regulations: that thatched roof (incidentally, the first to be permitted for a major building in London since the Great Fire of 1666) contains a sprinkler system.

In addition to striving for authenticity with regard to the building, the Globe had (and to some extent still has) a mission to recreate the original conditions of production on Shakespeare's stage and to conduct research into all aspects of the drama of his time. This includes work on the theatre companies and their repertories as well as on things like costumes and props. It is a kind of laboratory for finding things out about Elizabethan and Jacobean theatre. Not only does it run a professional season from April to October (containing six plays in repertory most years), but it has an ongoing project to perform and record staged readings of all of the three hundred and seventy-two plays that are extant from the period. It also invites overseas companies to perform: as I write in 2012, as part of the 'Cultural Olympiad' associated with the London Olympic Games, there is an ambitious 'Globe to Globe' season with 37 companies performing 37 plays in 37 languages. Meanwhile Globe Education is running a series of talks, conferences and workshops under the heading 'Shakespeare: Found in Translation'.

Globe Education runs literally hundreds of events for schools and colleges and attracts international students at all levels. My own university, King's College London, runs two MA programmes jointly with the Globe, one on 'The Teaching of English' involving the King's Department of Educational and Professional Studies, and one on 'Shakespeare Studies: Text and Playhouse', involving me and my colleagues in the English Department. The publishers of the Arden Shakespeare (Bloomsbury) also sponsor a series of lectures at the Globe and make electronic versions of the texts available to the theatre practitioners.

But while this means that I am broadly sympathetic to Sam Wanamaker's project, it does not mean that I cannot be critical of some aspects of it. When we interview prospective students for the MA in Shakespearean Studies (which includes a compulsory course taught at the Globe), we always ask them what they think about the reconstruction of the theatre and whether it is in fact possible to achieve authenticity in relation to the staging of the plays. We encourage scepticism, or at least openmindedness, and in teaching the course we spend time discussing what we don't and perhaps can't know, as well as what we think we do know about these matters. In this essay I am going to look at some of the evidence we can use to establish how the plays 
may have been staged originally and how that evidence has been or could be used to stage the plays today. I'm going to begin with the obvious and important area of original stage directions. These may not be strictly authorial, but if they occur in texts of Shakespeare's plays published up to 1623 (when his friends and fellow actors at the Globe collected his works posthumously in the First Folio) they would seem to have a strong claim to be telling us something about what actually happened on the Globe stage.

\section{Stage directions}

In the fifth scene of all three of the early texts of Hamlet (two of them printed in 1603 and 1604, soon after the likely first production of the play around 1600, and the third printed in the First Folio in 1623), there is a stage direction specifying that the Ghost cries out from "under the stage". This is quite rare in Shakespeare, the only other example being in Antony and Cleopatra (written around 1606) where in Act 4, scene 3 we find the stage direction "Music of the Hoboys is under the stage". In both cases there is an association with the supernatural: the Ghost in Hamlet speaks as if from Hell or Purgatory and the music in Antony and Cleopatra is unearthly, described by the soldiers who hear it as "in the air" or "under the earth" and interpreted by one of them: "tis the god Hercules whom Antony loved / Now leaves him" (4.3.21-2). The "under the stage" direction is reasonably frequent in the work of other playwrights of the Early Modern period in English drama. The literal space beneath the main platform, accessed by means of one or more trapdoors, was often given a fictional designation and various sounds could emanate from it. Figures and properties could ascend and descend through the trapdoors. In the description of the dumb show (or mime) before Act 4 of Thomas Sackville and Thomas Norton's early Elizabethan tragedy Gorboduc (1561), for example, we are told that "there came out from under the stage, as though out of hell, three furies" and another ghost groans from under the stage in John Marston's Antonio's Revenge, written around the same time as Hamlet. This space could also be supposed to be a grave (as it is later in Hamlet), a gulf or pit (as in Act 2 of Shakespeare's early tragedy Titus Andronicus), or a cave (as in the last Act of the later Timon of Athens), although the stage directions in these instances do not explicitly require it.

In the case of the Ghost in 1.5, however, the direction "under the stage" is reinforced in the dialogue when Hamlet asks his companions to swear their silence and is echoed by the Ghost, "under the stage", saying "Swear", whereupon Hamlet exhorts them, "Come on, you hear this fellow in the cellarage" (1.5.159). It would be nice to think that "cellarage" was the technical term for the cellars under the stage, but there are no other examples of this usage. A few lines later the Ghost seems to have moved his position for his next intervention and Hamlet comments on this with "Well said, old mole, canst work i'th' earth so fast?" (1.5.170). Again the rare term "cellarage" (actually spelt "sellerige" or "selleredge") and the reference to the Ghost as "old mole" occur in all three early texts, so there is absolutely no doubt that, at the Globe in 1600, 
the actor playing the Ghost was indeed intended to spend the latter part of this scene "under the stage". He may have made his exit earlier in the scene by descending through a trapdoor into this space, but the texts do not specify this. At his later appearance in the play, in the closet scene, it seems that he used one of the stage doors for his exit from Hamlet's line, "Look where he goes even now out at the portal" (3.4.138).

It seems that the directions using the space under the stage were adhered to in the 1740s. The earliest surviving promptbook or annotated theatrical text of Hamlet is that of John Ward, the grandfather of Sarah Siddons and John Philip Kemble, who led a company on a regular touring circuit of the West Midlands and Welsh Borders. In Act 1 , scene 5, his copy is marked up with the notes "Ring for trap to be ready" and "Ghost ready below" at the appropriate points (Thompson: 1999). But at the reconstructed Globe in London in 2000, the Ghost in this scene left the stage by one of the stage doors and spoke from behind the actors in the tiring house, not from beneath their feet. It had turned out not to be practicable to have him under the stage: he could not be heard by the audience; nor could he hear his cues. We might deduce from this that it is the reconstruction that is at fault and that the acoustics of the 1600 Globe did allow for this staging. Or we might assume that it was always impracticable and that the Chamberlain's Men had to find a way of getting around it, as Mark Rylance's company did four hundred years later. It seems from the examples of "under the stage" directions listed in Alan C. Dessen and Leslie Thomson (1999) that Hamlet is unusual in requiring the actor under the stage to participate in a continuing dialogue rather than give a single cry or groan.

I have begun with this example in order to emphasize two points about the discussion of the staging of plays from this period in general and the 'authentic' staging practices associated with the reconstructed Globe in particular. First, that the stage directions in the earliest texts constitute a crucial body of evidence, and second, that we may sometimes have to question whether they always give an accurate reflection of what actually happened on stage. Editors and scholars who otherwise despise the First Quarto of Hamlet as a "Bad" text, nevertheless put some confidence in its stage directions on the grounds that it is a version of the text plagiarised or bootlegged by someone who acted in or attended one or more early performances. Hence the direction that the Ghost appears "in his night gown" in the closet scene and that Ophelia appears "playing on a lute, and her hair down, singing" in her mad scene are taken seriously as reflections of what actually happened on the Globe stage in 1600. Modern productions, whether at the reconstructed Globe or elsewhere, will make their own decisions about costuming the Ghost, depending on whether they want the closet scene to feel like an intimate domestic moment (the Queen is going to bed; her former husband appears as if about to do the same) or a more threatening and potentially aggressive invasion from another world (the Ghost appears in armour, as in Act 1). They will usually make their decisions about Ophelia's appearance and behaviour based on modern ideas about women and madness. 
Some of Shakespeare's stage directions seem challenging to even the best equipped contemporary theatres. The reconstructed Globe has not yet presented a full-scale version of the late Romance Cymbeline which contains one of my favourite stage directions in its final Act: "Jupiter descends in thunder and lightning, sitting upon an eagle. He throws a thunderbolt" (5.4.92). The Globe did present a small-scale experimental version of Cymbeline in 2001, but did not attempt the eagle. I have yet to see a remotely adequate representation of this moment on the modern stage, despite the use of all sorts of special effects and back projection. Scholars have argued that Cymbeline was written for the Blackfriars Theatre, a much smaller space than the Globe and, importantly, an indoor one, where artificial lighting was used and elaborate machinery was available, but we know from a contemporary account that it was also staged at the Globe in 1611. The modern Globe has presented a full-scale version of The Winter's Tale which contains the more famous stage direction, "Exit, pursued by a bear" for the final departure from the stage of Antigonus at the end of Act 3 (3.2.58); they took the conventional course of using an actor in a bear's costume, despite the earnest arguments of many Shakespeare scholars that the Bankside theatres were also used for bear-baiting and that the actors might have borrowed a performing bear on the afternoons when they were putting on The Winter's Tale. It has to be said that performing bears are not so readily available in Southwark these days.

The modern Globe has also presented Titus Andronicus with its equally famous stage direction for Lavinia to enter in Act 2 with "her hands cut off and her tongue cut out, and ravished" (2.3.0); in the next Act a messenger has to enter "with two heads and a hand" (3.1.234), the heads being those of two of Lavinia's brothers and the hand that of her father Titus, which has recently been severed on stage. Shakespeare calls for severed heads in several other plays, including 1 Henry VI, Richard III, King John and Macbeth; his company must have had some properties made to look like heads that could be stored and used repeatedly: the list or inventory of properties that survives from Henslowe's company, the rival Admiral's Men, in 1598 lists a variety of heads (2002). One interesting sidelight on how the actors supplied the prodigious amounts of blood required in many plays occurs in the surviving 'plot' or outline of George Peele's play, The Battle of Alcazar (1589) which stages a "bloody banquet" of dead men's heads and bones in dishes. A marginal note specifies the need for "three vials of blood and a sheep's gather" (that is, the heart, lungs and liver of a sheep), apparently implying that someone was sent round to the local butcher for supplies. It is not known how they cleaned the costumes afterwards. A further insight into how a severed head might have been staged comes from an illustration in Reginald Scott's Discovery of Witchcraft (1584), which illustrates how 'jugglers', or fake witches could achieve the effect by using a body double.

One final example of a stage direction from Hamlet in the graveyard scene (5.1), all three of the early texts have a stage direction for Laertes to leap into Ophelia's grave after he has said "Hold off the earth awhile / Till I have caught her once more in mine arms" (5.1.247-8). But the so-called "Bad" First Quarto is alone in having the direction "Hamlet leaps in after him". This piece of staging is supported by an anonymous elegy 
on Richard Burbage, the first actor to play Hamlet (and many more of Shakespeare's leading roles): "Oft have I seen him leap into the grave", this poet writes, and, assuming that a trapdoor was used as the grave, the moment could provide a striking visual parallel with the entrances and exits of the Ghost in Act 1, if indeed the trapdoor was used then. But for Hamlet to leap in after Laertes has proved unpalatable to many editors who argue that Hamlet cannot be the aggressor here: Laertes must come out of the grave to attack him. This essentially character-based interpretation of a moment of staging is comparable to a similar situation in the opening scene of As You Like It where editors routinely add stage directions to make it clear that Oliver (the bad brother) is the aggressor, not Orlando (the good brother), although the dialogue might imply otherwise.

Another consideration is visibility: when Giles Block directed Mark Rylance at the Globe in 2000, Rylance did indeed leap into the 'grave' made by a trapdoor, but the subsequent fight was very cramped, with three actors (including the 'corpse' of Ophelia) in the small space, and it was not easily visible from the yard. We included a photograph of this moment in our edition of the First Quarto as a piece of staging supposedly unique to that text, although the Globe production was actually based on the Folio (Thompson and Taylor, 2006). As with the location of the Ghost "under the stage" in 1.5, there seems to be a conflict between 'authentic' stage directions and practical stagecraft. We cannot expect the actors at the Globe to value 'authenticity' in such matters over the need to make a play work for a modern audience.

The use of the yard is a further area of debate. It is not clear from the early stage directions that actors in Shakespeare's time made entries or exits through the yard, except on the rare occasions when actors are placed amongst the audience and then supposedly interrupt the play by climbing onto the stage and taking part: this happens in Francis Beaumont's The Knight of the Burning Pestle (1607), for example, and probably in Ben Jonson's The Staple of News (1625). But locating action in the yard and encouraging interaction between the actors and the 'groundlings' has become a feature of performances at the modern Globe. In an early (1999) production of a nonShakespearean play, Beaumont and Fletcher's The Maid's Tragedy (1610), a dais was set up in the yard for the royal party to view the wedding masque at the beginning of the play. Lucy Bailey, who directed As You Like It in 1998, located the wrestling scene in the yard and later conceived Titus Andronicus in 2006 as a kind of promenade production in which the audience felt the actors were coming at them from all directions. A similar effect was achieved in the 2008 Timon of Athens, with actors coming down from above as well as from all sides. In the 2005 Pericles, the teaming of Kathryn Hunter as 'Master of Play' (the Globe's term for director) with Marcello Magni as 'Master of Physical Play' led to an excitingly athletic production with actors performing acrobatics, not just in the yard but in and around the balconies. More recent productions have routinely made use of the yard for entrances and exits, and actors frequently take advantage of the opportunities for by-play with audience members. 


\section{Casting, clothing and authenticity}

The Globe, under its first Artistic Director, Mark Rylance, tended to present seasons of plays linked loosely by a thematic concept (though his successor, Dominic Dromgoole, has discontinued this practice). 2001, for example, was billed as 'The Celtic Season' and included Macbeth and King Lear; 2002 was 'The Season of Star-Crossed Lovers' and included Romeo and Juliet and Measure for Measure. Other labels have been more fanciful: another 2002 theme was 'The Season of Cupid and Psyche', including A Midsummer Night's Dream and Twelfth Night, while the 2005 'Season of the World and the Underworld' included Pericles and The Tempest. 2003 was 'The Season of Regime Change' and the programmes for two of the plays that year, Richard III and The Taming of the Shrew, contained some remarks by Stewart Pearce ('Master of Voice', the Globe's term for Voice Coach) beginning "Our first all-female company marks a glorious aspect of regime change". On the opposite page, Jemimah Tomlinson (Deputy Wardrobe Manager) contributed a short essay beginning "This theatre season is the first in which the Globe has presented four original practice productions in repertory. The clothes have been handmade out of silk, wool or linen and interlined with either wool or horsehair". These apparently conflicting statements point again to the tension that has been present at the Globe from the beginning: how to reconcile the claims that both the building and the plays put on there represent authentic reconstructions of Shakespeare's time ('original practices') and the need to satisfy the requirements of modern actors and audiences. It has often been said that, while it is possible to achieve high levels of authenticity in material things like the building methods used and the meticulous reconstruction of costumes, we cannot reconstruct the social context of the original theatre or the people who inhabited it. And the Globe is not a museum or a piece of the heritage industry, but a living theatre which receives no public subsidy and needs to attract audiences to keep going.

The Globe has indeed become a focus of serious research into sixteenth-century textiles and clothing. The ten members of the wardrobe department take enormous pains not only to use authentic materials and fastenings (no zips, poppers or velcro; everything has to be laced, pinned or buttoned), but to prepare and care for the costumes in the same way that the Elizabethans would have done. For example, in the aforementioned programme essay, Jemimah Tomlinson explains:

All collars and cuffs are starched using rice starch boiled and prepared on the premises. Ruffs must be ironed, pinned into figure-of-eight segments and shaped around hot iron pokers, a process which can take up to six hours. Nothing is dry-cleaned and we use a combination of vodka and rose water to counteract what is often an all-too-authentic smell.

A single ruff can in fact contain as much as twenty yards of fine, hand-sewn linen. This level of detail is probably lost on most members of an audience (and indeed is not really intended for them), but is it even appropriate in the search for authenticity? We have only one early seventeenth-century illustration of a Shakespeare play on the stage, 
Henry Peacham's drawing of a scene from Titus Andronicus (Richard Proudfoot, Ann Thompson and David Scott Kastan 2001: 6). It seems to show an eclectic mix of costumes: the soldiers on the left wear Elizabethan armour and carry halberds, Titus wears a kind of toga to reflect the Roman setting, while the gown of the kneeling Tamora is vaguely oriental or even medieval. References to costumes in the play-texts themselves do indicate that the actors wore mainly contemporary costumes regardless of the chronological or geographical settings of the plays: Caska in Julius Caesar refers to Caesar's doublet (1.2.264), Coriolanus stands in the forum waving his hat (2.3.165) and Cleopatra, pretending to be fainting, asks one of her attendants to cut her lace (1.3.72). King Lear contains references to breeches (1.4.165), worsted stockings (2.2.16), cod-pieces (3.2.27) and spectacles (1.2.36). Audiences must have seen on stage clothing quite similar to what they would have seen on the streets of London, whereas to present King Lear in meticulous Jacobean costume today is to make a statement about it as a play from a specific period and arguably to restrict its range of meaning. But critics and audiences complain when the Globe stages plays, such as Macbeth in 2001, in modern dress. This was obviously anticipated by the Master of Play, Tim Carroll, who contributed a slightly defensive essay to the programme, arguing for the "timeless" quality of the play.

Perhaps a more famous and contentious issue in the authenticity debate is that of casting. It is well known that professional theatre companies in Shakespeare's time were all-male; his company usually contained ten adult males and three or four boys (apprentice actors) to play the women's parts. This obviously affected the kinds of characters he could present: there are relatively few parts for older women in the plays (and a notorious absence of mothers), and heroines tend to be somewhat isolated in a male world, sometimes disguising themselves as men in order to survive. The Globe has, from the start, presented a number of all-male productions, including Henry $V$ (1997), Julius Caesar and Antony and Cleopatra (1999), Twelfth Night (2002) and Richard II (2003), this last play appearing alongside the all-female productions in 'The Season of Regime Change'. They have not, however, on the whole, cast boys in the women's roles, or even particularly young men; Toby Cockerell, who doubled the Princess of France and the Boy in Henry $V$ and Eddie Redmayne, who played Viola in Twelfth Night, were both around twenty -somewhat older than Shakespeare's boy actors- and Rylance himself (at around forty) has played Cleopatra and Olivia. (He is about to reprise his Olivia, ten years on, in 2012). Other adult men have also been cast as women: Paul Chahidi played Maria in Twelfth Night and William Osborne played the Duchess of York in Richard II.

The all-female productions of 2003, while totally inauthentic, were refreshing for audiences, though not without their difficulties for the performers. Both were slated to be directed by a man, Barry Kyle, and while this seems to have worked all right for Richard III, the cast of The Taming of the Shrew apparently found his approach to the play unacceptable and he stepped down in the midst of rehearsals in favour of a woman, Phyllida Lloyd. He was philosophical about this in the press at the time, remarking, in a deliberate misquotation from the play, "Thus have I politicly ended my reign" 
(4.1.176). The programme contained a tactful acknowledgement: "This production was conceived and cast by Barry Kyle and staged by Phyllida Lloyd". While most of the single-sex productions at the Globe have been relatively straightforward, allowing the audience to overlook or genuinely forget the gender issue, The Shrew turned it into the major focus, with Janet McTeer as a brash Petruchio who began by urinating against one of the stage pillars and later carried the diminutive Kathryn Hunter (who played Kate) over one shoulder. It was a deliberate parody of a macho performance and one of my favourite moments was an equally inauthentic one, namely the role of the dog in the chaotic scene when Kate is brought back to Petruchio's house as his unwilling bride. It is true that in the text Petruchio asks "Where's my spaniel Troilus?" (4.1.138), and in some productions a dog does appear to add to the confusion of the servants milling about and Petruchio throwing the food and dishes at them, but here an (un-credited) actor was dressed as a very large, woolly dog which towered over Kate and seemed to threaten her. When Petruchio wasn't looking, she kicked it, losing some of the sympathy of the audience who had been on her side until that moment.

Kathryn Hunter, who also starred as Richard III (and had directed The Comedy of Errors in 1999; she went on to direct Pericles in 2005), is known as a leading member of the experimental company, Theatre de Complicite, as is Marcello Magni who has played a number of parts at the Globe, including ones in both the plays Hunter directed. Lilo Bauer, another Complicite actor, has also performed there; the casting of such actors signals the intention of the Globe to engage with contemporary theatre and not to be isolated from it. Rylance was sometimes criticised for not bringing in 'big name' actors to compete with himself, but some 'big name' actors simply refuse to perform at the Globe and he has employed a number of actors who are very well known, at least in the U.K., such as Eve Best, Jasper Britton, Julian Glover, Anastasia Hille, Corin and Vanessa Redgrave.

Further opportunities for female performers occurred in the 2005 production of Troilus and Cressida which employed a kind of one-sided gender-blind casting, allowing women to play Agamemnon, Ulysses and Nestor, for example, while women also played Cressida and Helen. No male actors took female roles in this production (there are not many female parts in the play), but Penelope Beaumont in particular relished her role as Ulysses, having previous played male roles such as Stanley in Richard III and Vincentio in The Shrew, and Yolanda Vazquez turned in a strong Agamemnon, having previously played Hortensio in The Shrew. An all-female Much Ado About Nothing followed in 2004, with Beaumont playing Leonato, the Governor of Messina, and Vazquez playing Beatrice. Perhaps surprisingly, and probably inadvertently, the Globe has to date given slightly more opportunities for women to play major male roles on its stage than it has given men to play major female roles another consequence of the fact that there are simply more major male roles available in the Shakespeare canon.

Troilus and Cressida had a limited number of performances, not so much because of its unusual casting as because of another experiment: it was billed as an Original Pronunciation production. With the help of the linguist, David Crystal, the Globe had 
offered a small number of performances of Romeo and Juliet in Original Pronunciation in 2004, running in the same season as a much larger number of performances in standard modern pronunciation. We cannot be totally sure what Shakespeare's pronunciation was like, but we can tell a great deal from rhymes, jokes and puns, and from some written characteristics such as spellings and elisions. The Globe was certainly taking a risk here, though one very much in line with its 'original practices' mission. To everyone's surprise, the Original Pronunciation performances went much faster than the regular ones, knocking some twenty minutes off the overall playing time. No comparison was possible in the case of Troilus because all performances were in Original Pronunciation, but it seemed to me an extremely fast presentation of the full text of a long and linguistically complicated play. Audiences did not seem to have too much difficulty picking up the unusual sounds; indeed many people remarked that the actors sounded more natural or 'like us' than usual, picking up on the fact that several features of the speech they heard sounded like modern British regional accents, especially western and northern ones.

Like most theatres today, the Globe has practised race-blind casting, employing black and Asian actors across a wide range of roles. It also, of course, cast a black actor as Othello in 2007 although there is no doubt that the original actor of the role, Richard Burbage, was white. Again like most theatres, it has usually employed much larger numbers of actors for each production than Shakespeare would have had, refraining from experimenting with what most scholars would consider to be authentic doubling practices. Finally, under the topic of 'casting' one should note that the Globe has also put on productions with very minimal casts involving complicated doubling patterns: their 2001 Cymbeline had only six actors and two musicians, and the 2005 Tempest had just three actors and three dancers. Many playgoers confessed to becoming confused, especially in the case of Cymbeline which is not a very well-known play. But at least the Globe cannot be accused of trying to turn the clock back in this area: they have experimented with 'original practices', but they have also used their space for a wide range of different styles of performance.

\section{Lighting, sound effects, and the weather}

The Globe is of course an open-air theatre. On hot days in summer, the box office often has to deal with enquiries as to whether it is air-conditioned, to which I understand the official answer is 'Naturally'. Performances in Shakespeare's time would have been entirely by daylight in the afternoons; the modern Globe does have electric lighting for evening performances, but it is 'flat' lighting whereby the audience is in the same light as the actors, as they would be in daylight. There are no spotlights and no use of lighting to create special effects. To illustrate again from Hamlet, the opening scene in all three texts contains some challenges for a modern company performing in daylight (or simulated daylight) in an open-air theatre. For a start, the time-scheme is highly compressed: "Tis now struck twelve", says Barnardo in the fifth line of the play, while 
in line 165 Horatio says: "But look, the morn in russet mantle clad,/ Walks o'er the dew of yon high eastward hill". We have moved from midnight to dawn in a very short period of stage-time, with no artificial lighting effects to assist in the illusion. The night is even more truncated in the scene at the supposed tomb of Hero in Much Ado About Nothing where there are only eleven lines between the appeal to "Midnight" to "assist our moan" and the observation that "the gentle day ... Dapples the drowsy east with spots of grey" (5.3.16-27). Although night-time scenes must always have been a challenge at the Globe, Shakespeare uses them quite frequently; the actors probably carried lanterns or torches to indicate to the audience that it was supposed to be dark. Most companies who perform in the open air today seem to avoid plays with several night-time scenes, such as Hamlet and Macbeth, but Shakespeare and his audiences clearly took them in their stride. Scenes very often begin with characters telling each other where they are (there was no scenery either), what time of day it is and what the weather is like. Dawn in the first scene of Hamlet is heralded by the crowing of a cock ("It was about to speak when the cock crew", says Barnardo of the Ghost at 1.1.152). Modern productions normally use a recorded sound effect, but an actor was used to mimic the sound of the bird at the Globe in 2000, as was probably done originally. Again we have the annotation in John Ward's promptbook from the 1740s which reads "one ready to crow" some thirty lines before the effect is needed (see essay). And of course this opening scene contains a Ghost who appears not once but twice. Modern productions normally have recourse to 'spectral' lighting, music and other special effects to enhance the eeriness of these moments, but the actors at Shakespeare's Globe, then and now, have to rely more exclusively on their own skill.

The Globe project in London includes a longer term plan to build a replica of the indoor Blackfriars Theatre that Shakespeare's company started using around 1609 (though they continued to use the Globe). This will not be on its original site but adjacent to the Globe itself, and will, on current planning, host a separate, winter company, allowing performances to take place all year round. Of course the U.S. already has such a reconstruction, at Staunton, Virginia, though so far modern safety regulations mean that they have not been able to experiment with the effects of performances by candlelight. There is a plan to build a reconstruction of the Globe at Staunton, too, using a modified version of the original dimensions, but employing modern building methods.

The modern environment adds its own sound effects, of course, with passing helicopters and the sirens of emergency vehicles being the most intrusive. The actors always have to choose whether to pause or just carry on. However, if you walk the short distance from the original site of the Globe (not quite where it is today but very close) to the excavations of the Rose Theatre in Sumner Street, you will realise that noise pollution or contamination may well have been a problem for Burbage and his fellows too: if the Rose was presenting a particularly noisy play -Marlowe's Tamburlaine, for example- or perhaps offering an afternoon of bear-baiting, the sounds of weapons and drums and the shouts of the actors and spectators must easily have been heard at the Globe. 
And then there is the weather. Shakespeare's company performed most often in winter, since outbreaks of the plague frequently caused the theatres to be closed in the warmer months. Today's Globe companies perform in summer, but in England there is no guarantee of clement weather conditions. They never cancel: I have seen both $A$ Midsummer Night's Dream and 1 Henry IV performed in torrential rain, and Hamlet, perhaps more appropriately, open in a thunderstorm. When the King arranges for Hamlet to be sent to England, intending that he will be executed there, in the First Quarto (but not in the more familiar texts) he pretends that this is:

For Hamlet's welfare and his happiness.

Haply the air and climate of the country

May please him better than his native home. (11.122-4)

The First Quarto has not yet been performed on the modern Globe stage (though a touring production in 2011 -to be reprised in 2012- did make some reference to it), but similar remarks about the English climate in other plays are received as ironic and greeted with laughter, especially if it happens to be raining. Sometimes quite fortuitous effects are created: in a production of The Tempest in 2000 (not the 2005, three-person version), the fact that both Ariel and Prospero came down from the shelter of the stage into the steady rain in the yard at the end added an unexpected poignancy to the surrender of magic. Under Mark Rylance, it became traditional for the Globe to put on a midnight performance on Midsummer Night: totally inauthentic, but quite magical if the dawn was beginning to break as the play ended.

I have been fortunate to have seen most of the professional productions of plays by Shakespeare and his contemporaries at the Globe since it opened and have learnt a good deal as a scholar about how things might have been done originally. I have also enjoyed seeing how the space can be used in new, totally 'inauthentic' ways, including for the performance of new plays. The production of The Front Line by Che Walker (2008, revived in 2009) transformed the Globe into the area of London around Camden Town tube station, and the production of Frank McGuinness's version of Euripedes' Helen in 2009 gave us an impressionistic version of ancient Egypt. The effort to recreate 'original practices' is admirable, but by no means the only aim of the theatre which has a special atmosphere that goes far beyond the obligations of authenticity. At the root of it is the relationship between the actors and their audiences, which is much more demanding and indeed risky for the actors than it is in most modern 'theatres in the round' where the lighting arrangements usually allow them to continue to ignore the audience, just as they would do if they were behind a proscenium arch. This is impossible at the Globe, where it has become evident that a kind of 'crowd control' is an important element in an actor's repertory of skills: he or she has to learn to manage a much more volatile situation than they are used to, especially if, like most modern performers, they are more experienced in television and film work, or in the kind of theatre where the audience sits passively in the dark. Paradoxically, it is the reconstruction of Shakespeare's Globe that has reminded us what 'living theatre' really means, in our own time as well as in his. 


\section{References}

Dessen Alan C. and Leslie Thomson (1999): A Dictionary of Stage Directions in English Drama, 1580-1642. Cambridge University Press.

Foakes, R.A. ed. (2002): Henslowe's Diary. R. A. Foakes, Cambridge University Press.

Shakespeare, William (2001): Complete Works. Richard Proudfoot, Ann Thompson and David Scott Kastan, eds. Second edition. London: The Arden Shakespeare. All references of Shakespeare's plays are to this edition.

(2006): Hamlet: The Texts of 1603 and 1623, Ann Thompson and Neil Taylor, eds. London: The Arden Shakespeare.

Thompson, Ann (1999): "'I'll have grounds more relative than this': the puzzle of John Ward's Hamlet promptbooks". In Yearbook of English Studies 29 (1999), 138-50). 